ISSN: 2302-8556

E-Jurnal Akuntansi Universitas Udayana

Vol.26.1.Januari (2019): 281-309

DOI: https://doi.org/10.24843/EJA.2019.v26.i01.p11

\title{
Pengaruh Kemampuandan Keterlibatan Pengguna Pada Efektifitas SIA Dengan Budaya Organisasi Sebagai Pemoderasi
}

\author{
Putu Pande Ryan Ananta Astika Putra ${ }^{1}$ \\ I G.A.M. Asri Dwija Putri \\ ${ }^{1,2}$ Fakultas Ekonomi dan Bisnis Universitas Udayana (Unud), Bali, Indonesia \\ e-mail: ryanananta186@icloud.com
}

\begin{abstract}
ABSTRAK
Tujuan penelitian ini adalah untuk mengetahui pengaruh kemampuan pengguna dan Keterlibatan Penggunapada keefektifan penggunaan SIA pada perusahaan SPPBE di Bali, dan untuk mengetahui pengaruh budaya organisasi dalam memoderasi kemampuan dan keterlibatan pengguna pada SIA di perusahan tersebut. Populasi dalam penelitian ini adalah karyawan pengguna SIA di seluruh perusahaan SPPBE di Bali.Metode pengambilan sampel menggunakan metodenon-probability sampling dengan teknik sampling jenuh, maka jumlah sampel ditentukan sebanyak 165 orang.Teknik analisis yang digunakan, yaitu dengan menggunakan teknik Moderated Regression Analysis.Berdasarkan hasil penelitian menunjukkan bahwa Kemampuan dan keterlibatan Pengguna berpengaruh positif dan signifikan serta budaya organisasi mampu memoderasi pengaruh kemampuan dan keterlibatan pengguna terhadap keefektifan penggunaan SIA.

Kata kunci : kemampuan pengguna, keterlibatan pengguna, efektifitas SIA, budaya organisasi
\end{abstract}

\footnotetext{
ABSTRACT

The purpose of this study was to determine the effect of user ability and user involvement on the effectiveness of SIA use in SPPBE companies in Bali, and to determine the influence of organizational culture in moderating the ability and involvement of users in SIA in the company. The population in this study were employees of SIA users in all SPPBE companies in Bali. The sampling method is non-probability sampling with saturated sampling technique, so the number of samples is 165 people. The analysis technique used is using the Moderated Regression Analysis technique. Based on the results of the study indicate that the ability and involvement of users have a positive and significant influence and organizational culture is able to moderate the influence of ability and user involvement on the effectiveness of the use of SIA.

Keywords: user ability, user involvement, effectiveness of SIA, organizational culture
} 
Putu Pande Ryan Ananta Astika Putra dan I G.A.M. Asri Dwija Putri. Pengaruh...

\section{PENDAHULUAN}

Perkembangan teknologi dan dunia bisnis yang semakin pesat menuntut kesiapan para pelaku bisnis untuk terus beradaptasi. Perkembangan teknologi informasi berdampak signifikan terhadap Sistem Informasi Akuntansi (SIA). Sistem Informasi Akuntansi adalah suatu sistem yang dijadikan pedoman dalam melaksanakan berbagai aktivitas operasi perusahaan dalam rangka menghasilkan informasi yang relevan, diantaranya mencatat data yang berkaitan dengan akuntansi perusahaan, memproses dan menganalisa data serta menyajikan informasi kuantitatif yang akhirnya akan membentuk laporan keuangan. Laporan keuangan adalah catatan informasi keuangan suatu perusahaan pada suatu periode akuntansi yang dapat digunakan untuk menggambarkan kinerja perusahaan tersebut. Laporan keuangan perusahaan merupakan suatu hal yang penting dalam rangka pembuatan keputusan yang berkaitan dengan bisnis perusahaan. Pembuat keputusan sangat mengharapkan informasi yang akurat, tepat waktu, relevan dan valid, sehingga pembuat keputusan akan dapat menghasilkan atau memberikan keputusan yang tepat dan sesuai dengan kondisi perusahaan pada saat yang bersangkutan.

Pesatnya perkembangan sistem informasi dan teknologi informasi menjadikannya senjata persaingan yang wajib dimiliki oleh perusahaan dalam memenangkan persaingan. Keberhasilan penerapan teknologi sistem informasi selain perangkat keras dan perangkat lunak, ditentukan pula oleh pengguna teknologi, sehingga aspek keperilakuan pengguna menjadi penting dan diperhatikan dalam 
ISSN: 2302-8556

penerapan teknologi informasi (Suartana dan Sudiadnyani, 2014). Persaingan bisnis yang semakin ketat membuat perusahaan - perusahaan membutuhkan sistem informasi yang berkualitas sebagai salah satu pendukung agar bisnis dapat berjalan dengan baik.

Penelitian ini dilakukan pada Stasiun Pengisian dan Pengangkutan Bulk Elpiji (SPPBE) Bali.Alasannya, karena saat ini Stasiun Pengisian dan Pengangkutan Bulk Elpiji (SPPBE) merupakan salah satu perusahaan yang sangat dibutuhkan oleh masyarakat sebab SPPBE menyediakan gas elpiji yang merupakan salah satu barang yang sangat penting khususnya dalam kehidupan sehari-hari. SPPBE merupakan perusahaan yang bergerak dalam bidang pengisian Gas Elpiji 3Kg. SPPBE bertugas untuk melayani penyaluran Gas Elpiji $3 \mathrm{Kg}$ kepada agen-agen yang berdomisili di Provinsi Bali, dengan metode-metode yang efisien, terpercaya, dan aman bagi lingkungan. Oleh karena perusahaan SPPBE merupakan perusahaan yang menyediakan salah satu kebutuhan primer masyarakat maka perusahaan jenis ini haruslah memiliki sistem informasi yang dapat reliabel dan valid untuk dapat membantu perusahaan menjalankan bisnisnya. Namun fenomena yang terjadi pada perusahaan SPPBE di Provinsi Bali yaitu tidak semua cabang menerapkan penggunaan sistem informasi akuntansi, sehingga masih terdapat beberapa kendala dan belum tepat sasaran, seperti kekurangan stok sehingga pemenuhan kebutuhan di agen-agen LPG tidak merata. Pemenuhan kebutuhan yang tidak merata ini juga disebabkan oleh jarak antar agen yang terkadang terlalu berjauhan atau terlalu berdekatan. Sehingga pelaku distributor juga susah dalam melakukan perannya secara 
Putu Pande Ryan Ananta Astika Putra dan I G.A.M. Asri Dwija Putri. Pengaruh...

maksimal. Akan tetapi dengan menggunakan sistem informasi berbasis web diharapkan bisa membantu pihak sales distribusi dan bagian penjualan LPG untuk mempermudah dalam pemantauan distribusi LPG. Berbagai hal tentu perlu dilakukan untuk membuat sistem agar menjadi menarik dan terstruktur.Maka dari itu diperlukan sistem informasi yang dibangun tentunya tidak sekedar menampilkan informasi baik dalam bentuk teks maupun gambar tetapi juga terdapat beberapa fitur dan menu yang dapat memberikan nilai tambah serta tepat sesuai dengan kebutuhan yang diperlukan.

Hal tersebut dapat dicapai jika perusahaan memiliki sumber daya manusia yang memiliki kompetensi dan juga memiliki partisipasi dalam pengembangan serta pelaksanaan sistemnya. Sumber daya manusia yang dimiliki oleh perusahaan ini dapat berubah menjadi lebih baik atau lebih buruk berkenaan dengan hal sifat dan kebiasaan, dan hal tersebut dapat dipengaruhi oleh budaya organisasi yang diterapkan oleh perusahaan tersebut. Suatu perusahaan dalam menjalankan sistem informasi tentu membutuhkan beberapa faktor pendukung, salah satu faktor penting yang dapat mendukung sistem informasi agar dapat memberikan informasi yang baik adalah pengguna dari sistem itu sendiri. Dalam hal ini pengguna dari sistem informasi tidak lain adalah karyawan yang bekerja di perusahaan tersebut. Karyawan sebagai pengguna sistem diharapkan memiliki kompetensi yang baik untuk menghindari terjadinya human error pada proses pengoperasian sistem. Keterlibatan pengguna (user involvement) dalam perancangan dan pengembangan sistem informasi lebih ditekankan pada bagaimana peranan pemakai dalam proses perancangan sistem informasi dan langkah-langkah apa yang akan dilakukan dalam mendukung dan 
ISSN: 2302-8556

mengarahkan kontribusinya. Doll dan Torzadekh (1989) mendefinisikan tingkat keterlibatan pengguna sebagai seberapa banyak partisipasi yang sesungguhnya (actual) diberikan oleh pemakai, dan partisipasi yang diinginkan (desired) oleh pemakai di dalam aktivitas pengembangan sistem. Keterlibatan pengguna merupakan keterlibatan dalam proses pengembangan sistem oleh anggota organisasi atau anggota dari kelompok pengguna target. Hasil penelitian yang dilakukan oleh Komara (2005) dan Perbarini (2014) serta Kharisma dan Juliarsa (2017) menemukan bahwa keterlibatan pemakai berpengaruh signifikan terhadap keefektifan kinerja sistem informasi akuntansi dalam perusahaan. Apabila pengguna terlibat secara langsung dan juga signifikan maka akan semakin efektif sistem informasi akuntansi yang akan diberikan oleh perusahaan tersebut kepada pemilik.

Selain dari keterlibatan pengguna sistem, kemampuan pengguna sistem juga sangatlah penting untuk dapat menjalankan sistem informasi akuntansi yang tersedia di dalam perusahaan agar lebih efektif dan efisien dalam penggunaannya. Kemampuan pengguna merujuk kepada bagaimana individu dalam perusahaan tersebut dapat melaksanakan pekerjaannya dengan baik. Kemampuan pengguna berorientasi kepada pengetahuan dan juga ketrampilannya dalam mengaplikasikan sistem informasi akuntansi yang digunakan dalam perusahaan tersebut. Kemampuan pengguna sistem dapat diklasifikasikan menjadi dua yaitu soft skill dan hard skill yang dimilikinya. Soft skill mengacu kepada pengetahuan atau teori-teori yang dipelajarinya mengenai sistem informasi akuntansi yang digunakan dalam perusahaan tersebut, sedangkan hard skill merupakan pengaplikasian dari apa yang ia telah 
Putu Pande Ryan Ananta Astika Putra dan I G.A.M. Asri Dwija Putri. Pengaruh...

pelajari mengenai sistem informasi akuntansi yang diterapkan dalam perusahaan tersebut. Hasil penelitian Perbani (2014), Daryani (2013) serta Kharisma dan Juliarsa (2017) mendapatkan hasil bahwa kemampuan pengguna memiliki pengaruh yang signifikan terhadap kinerja sistem informasi akuntansi perusahaan. Kemampuan dari pengguna sistem informasi menentukan efektif tidaknya sistem informasi akuntansi yang diterapkan oleh perusahaan tersebut, semakin tinggi kemampuan pengguna dalam mengaplikasikan sistem informasi akuntansi perusahaan maka akan semakin efektif penggunaan sistem informasi akuntansi di perusahaan tersebut.

Sikap dari pengguna informasi dapat dipengaruhi oleh budaya organisasi yang dimiliki oleh perusahaan yang bersangkutan. Budaya organisasi merupakan nilai-nilai yang berkembang dalam suatu organisasi dan mengarahkan perilaku anggotaanggotanya. Budaya organisasi dapat menjadi instrumen keunggulan kompetitif yang utama, yaitu bila budaya organisasi mendukung strategi organisasi dalam mencapai tujuan yang diinginkannya. Budaya organisasi mempunyai pengaruh terhadap perilaku, cara kerja dan motivasi para manajer dan bawahannya untuk mencapai kinerja organisasi. Budaya yang ada pada suatu organisasi akan mempengaruhi cara pekerjaan dilakukan dan cara para pekerja berperilaku serta menyebabkan para pekerja memiliki cara pandang yang sama dalam melaksanakan aktivitas pekerjaan. Budaya merupakan faktor yang sangat penting dalam meningkatkan efektivitas organisasi. Menurut penjelasan tersebut maka dapat disimpulkan bahwa budaya organisasi dapat memperkuat atau memperlemah kemampuan serta keterlibatan pengguna dalam mengaplikasikan sistem informasi yang ada di perusahaan tersebut, 
ISSN: 2302-8556

sehingga dalam penelitian ini budaya organisasi digunakan sebagai variabel pemoderasi terhadap hubungan kemampuan serta keterlibatan pengguna dalam mengaplikasikan sistem informasi.

Dari uraian latar belakang di atas, rumusan masalah pada penelitian ini yaitu: 1) Apakah kemampuan pengguna dan keterlibatan pengguna mempengaruhi keefektifan penggunaan sistem informasi akuntansi pada perusahaan SPPBE di Bali?; 2) Apakah budaya organisasi memoderasi kemampuan pengguna dan keterlibatan pengguna pada keefektifan SIA pada perusahaan SPPBE di Bali?. Tujuan dalam penelitian ini adalah untuk memberi bukti empiris pengaruh kemampuan pengguna dan keterlibatan pengguna pada keefektifan penggunaan sistem informasi akuntansiserta untuk memberi bukti empiris pengaruh budaya organisasi dalam memoderasi hubungan antara kemampuan dan keterlibatan pengguna pada keefektifan SIA pada perusahaan SPPBE di Bali.

Dari tujuan penelitian, peneliti berharap berdasarkanhasil penelitian ini dapat memberikan kegunaan secara teoritis maupun praktis. Kegunaan teoritis dalam penelitian dilakukan, diharapkan berguna bagi para akademisi sebagai bahan acuan dalam melanjutkan penelitian yang lebih mendalam terutama pada topik yang serupa. Sedangkan kegunaan praktis penelitian ini diharapkan dapat memberikan informasi serta bukti yang nyata mengenai moderasi budaya perusahaan dalam pengaruh kemampuan pengguna, dan keterlibatan pengguna pada keefektifan penggunaan model sistem informasi akuntansi pada perusahaan SPPBE di Bali. 
Putu Pande Ryan Ananta Astika Putra dan I G.A.M. Asri Dwija Putri. Pengaruh...

Kajian pustaka dalam penelitian ini adalah Technology Acceptance Model (TAM) dan Agency Theory (teori keagenan). Technology Acceptance Model merupakan suatu model untuk memprediksi dan menjelaskan bagaimana pengguna teknologi menerima dan menggunakan teknologi tersebut dalam pekerjaan individual pengguna. Tujuan TAM ini adalah untuk menjelaskan sikap individu terhadap penggunaan suatu teknologi. Sikap individu atau reaksi yang muncul dari penerimaan teknologi tersebut dapat bermacam macam diantaranya dapat digambarkan dengan intensitas atau tingkat pengguna teknologi tersebut (Davis, 1989). Hasil penelitian Davis menunjukkan bahwa faktor yang memengaruhi minat penggunaan sistem informasi dipengaruhi oleh persepsi kebermanfaatan (perceived usefulness) dan persepsi kemudahan penggunaan (perceived ease of use).

Teori Keagenan merupakan sebuah kontrak antara manajemen (agen) dengan pemilik (prinsipal). Agar hubungan kontraktual ini dapat berjalan lancar, pemilik akan mendelegasikan otoritas pembuatan keputusan kepada manajer. Perencanaan kontrak yang tepat bertujuan untuk menyelaraskan kepentingan manajer dan pemilik dalam hal konflik dan kepentingan, hal ini merupakan inti dari teori keagenan. Sebagai agen, manajer secara moral bertanggung jawab untuk mengoptimalkan keuntungan para pemilik (prinsipal) dan sebagai imbalannya akan memperoleh kompensasi sesuai dengan kontrak (Jensen dan Meckling, 1976). 
ISSN: 2302-8556

E-Jurnal Akuntansi Universitas Udayana

Vol.26.1.Januari (2019): 281-309

Secara sistematis, kerangka konseptual dalam penelitian ini dapat dilihat pada Gambar 1 sebagai berikut.

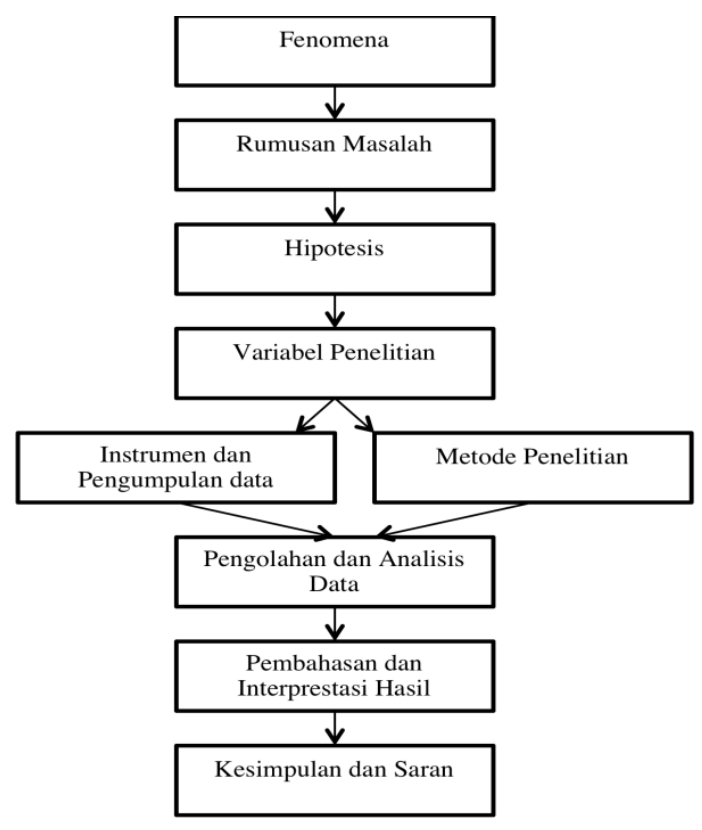

Sumber: Data diolah, 2018

\section{Gambar 1. Kerangka Konseptual}

Pengguna sistem informasi merupakan fokus yang penting berkaitan dengan efektifitas sistem informasi, karena pengguna sistem informasi lebih banyak mengetahui permasalahan yang terjadi dilapangan. Keberhasilan dan keefektifan suatu sistem informasi tidak hanya ditentukan oleh kecanggihan sistem tersebut tetapi ditentukan oleh kesesuaiannya dengan para pengguna sistem tersebut. Penelitian ini mengacu kepada penelitian serupa yang dilakukan oleh Perbani (2014), Daryani (2013) serta Kharisma dan Juliarsa (2017) yang mendapatkan hasil bahwa kemampuan pengguna memiliki pengaruh yang signifikan terhadap kinerja sistem informasi akuntansi perusahaan. Kemampuan dari pengguna sistem informasi 
menentukan efektif tidaknya sistem informasi akuntansi yang diterapkan oleh perusahaan tersebut, semakin tinggi kemampuan pengguna dalam mengaplikasikan sistem informasi akuntansi perusahaan maka akan semakin efektif penggunaan sistem informasi akuntansi di perusahaan tersebut. Berdasarkan uraian diatas, maka dapat dirumuskan hipotesis sebagai berikut:

$\mathrm{H}_{1}$ : Kemampuan Pengguna Berpengaruh Positif Pada Keefektifan Penggunaan Sistem Informasi Akuntansi di Perusahaan SPPBE di Bali.

Keterlibatan pengguna merupakan keterlibatan dalam proses pengembangan sistem oleh anggota organisasi atau anggota dari kelompok pengguna target. Penelitian ini mengacu kepada penelitian yang dilakukan oleh Komara (2005) dan Perbarini (2014) serta Kharisma dan Juliarsa (2017) yang menemukan bahwa keterlibatan pemakai berpengaruh signifikan terhadap keefektifan kinerja sistem informasi akuntansi dalam perusahaan. Penelitian tersebut memiliki kesamaan dengan hasil penelitian dari Surya dan Suardikha (2016) namun bertentangan dengan penelitian yang dilakiukan oleh Dartani (2013) yang mendapatkan hasil bahwa keterlibatan pemakai tidak berpengaruh terhadap keefektifan kinerja system informasi akuntansi perusahaan. Sesuai yang dipaparkan diatas pengguna sistem informasi merupakan hal yang sangat penting berkaitan keefektifan sistem informasi akuntansi perusahaan, apabila pengguna terlibat secara langsung dan juga signifikan maka akan semakin efektif sistem informasi akuntansi yang akan diberikan oleh perusahaan tersebut kepada pemilik. Berdasarkan uraian diatas, maka dapat dirumuskan hipotesis sebagai berikut: 
ISSN: 2302-8556

E-Jurnal Akuntansi Universitas Udayana

Vol.26.1.Januari (2019): 281-309

$\mathrm{H}_{2}$ : Keterlibatan Pengguna Berpengaruh Postif Pada Keefektifan Penggunaan Sistem Informasi Akuntansi di Perusahaan SPPBE di Bali.

Budaya Organisasi dapat mempengaruhi sifat atau kebiasaan dari karyawan dalam suatu perusahaan, dengan begitu budaya perusahaan akan berpengaruh langsung pada kemampuan dan juga keterlibatan pengguna sistem informasi akuntansi. Dimana dengan kuatnya budaya organisasi yang dimiliki oleh perusahaan itu akan membuat kemampuan pengguna sistem semakin meningkat. Beaudry dan Pinsonneault (2005) menempatkan budaya sebagai dampak implementasi sistem informasi yaitu cara penyesuaian diri pengguna terhadap sistem informasi pada fase pasca implementasi. Komponen budaya yang menjadi fokus kajian adalah kestabilan emosi pengguna setelah melewati fase perubahan akibat implementasi SI (restoring personal emotional stability), perilaku efektif dan efisien dalam bekerja, serta inisiatif untuk ikut serta meminimalkan dampak negatif pasca implementasi sistem informasi. Berdasarkan uraian diatas, maka dapat dirumuskan hipotesis sebagai berikut:

$\mathrm{H}_{3}$ : Budaya Organisasi Memoderasi Kemampuan Pengguna Pada Keefektifan Penggunasan Sistem Informasi Akuntansi di Perusahaan SPPBE di Bali.

Menurut Schein (1997) tampak bahwa budaya organisasi memiliki peran yang sangat strategis untuk mendorong dan meningkatkan efektifitas kinerja organisasi, sebagai instrumen untuk menentukan arah organisasi, mengarahkan apa yang boleh dilakukan dan yang tidak boleh dilakukan, cara mengalokasikan sumber daya organisasional, dan sebagai alat untuk menghadapi masalah dan peluang dari lingkungan internal dan eksternal. Sesuai dengan pernyataan diatas yang menjelaskan mengenai budaya kinerja atau budaya organisasi akan membuat karyawan semakin 
terdorong dalam berprestasi maka, dengan kuatnya budaya organisasi perusahaan akan memperkuat dan semakin membuat karyawan terlibat dalam penggunaan sistem informasi akuntansi yang akan membuat pengaplikasian sistem informasi akuntansi yang dimiliki oleh perusahaan tersebut semakin efektif. Berdasarkan uraian diatas, maka dapat dirumuskan hipotesis sebagai berikut:

$\mathrm{H}_{4}$ : Budaya Organisasi Memoderasi Keterlibatan Pengguna Pada Keefektifan Penggunaan Sistem Informasi Akuntansi di Perusahaan SPPBE di Bali.

\section{METODE PENELITIAN}

Penelitian ini menggunakan pendekatan kuantitatif yang berbentuk asosiatif. Penelitian ini menjelaskan tentang Apakah kemampuan pengguna dan keterlibatan pengguna pada keefektifan penggunaan sistem informasi akuntansi dengan budaya organisasi sebagai variabel pemoderasi. Lokasi penelitian dilakukan di SPPBE (Stasiun Pengangkutan dan Pengisian Bulk Elpiji). Objek penelitian yang menjadi kajian dalam penelitian ini adalah budaya organisasi perusahaan, kemampuan pengguna, keterlibatan pengguna serta keefektifan dari penggunaan sistem informasi akuntansi di perusahaan tersebut.

Populasi dalam penelitian ini adalah karyawan pengguna sistem informasi akuntansi di seluruh perusahaan SPPBE di Bali, yaitu sebanyak 165 karyawan pengguna sistem informasi. Metode pengambilan sampel yaitu non-probability sampling dengan teknik sampling jenuh, yaitu teknik penentuan sampel, bila semua anggota populasi digunakan sebagai sampel (Sugiyono, 2016:96), sehingga sampel 
dalam penelitian ini berjumlah 165 karyawan pengguna sistem informasi akuntansi yang terdapat di seluruh SPPBE di Bali.

Metode pengumpulan data yang pada penelitian ini adalah data primer yang diperoleh langsung dari SPPBE yang dapat diperoleh dengan metode survei yang dilakukan dengan pengumpulan data melalui pengisian kuesioner yang dapat dilakukan dengan mengunjungi responden penelitian ke lokasi penelitian. Hasil jawaban tersebut kemudian diukur dengan menggunakan skala likert, yaitu pilihan jawaban responden diberi nilai dengan skala 4 poin. Teknik analisis data pada penelitian ini adalah teknik analisis regresi moderasi (MRA) dihitung dengan SPSS. Pengujian dilanjutkan apabila model dalam penelitian telah memenuhi syarat yaitu data harustidak mengandung heteroskedastisitasserta multikolinieritas dan berdistribusi normal (uji asumsi klasik). Pengujian selanjutnya yaitu, uji kelayakan model (uji F) uji koefisien determinasi $\left(\mathrm{R}^{2}\right)$, setelah itu ujiregresi linier sederhana, uji MRA,uji hipotesis (Uji t), dan statistik deskriptif. Model regresi penelitian ini dapat ditunjukkan dengan persamaan sebagai berikut.

$\mathrm{Y}=\alpha+\beta 1 \mathrm{X} 1+\beta 2 \mathrm{X} 2+\beta 3 \mathrm{X} 1 \mathrm{X} 2+\mathrm{e}$

Keterangan:

\begin{tabular}{|c|c|}
\hline Y & $=$ Profitabilitas LPD \\
\hline$\alpha$ & $=$ Konstanta \\
\hline$\beta 1, \beta 2, \beta 3$ & $=$ Koefisien Regresi \\
\hline $\mathrm{X} 1$ & $=$ Kualitas Sistem Informasi Akuntansi \\
\hline $\mathrm{X} 2$ & $=$ Ketidakpastian Tugas \\
\hline $\mathrm{X} 1 \mathrm{X} 2$ & $\begin{aligned}= & \text { Interaksi antara Kualitas Sistem Informasi Akuntansi } \\
& \text { dengan Ketidakpastian Tugas }\end{aligned}$ \\
\hline $\mathrm{e}$ & $=$ Error Term, yaitu tingkat kesalahan dan penelitian \\
\hline
\end{tabular}




\section{HASIL DAN PEMBAHASAN}

Statistik deskriptif bertujuan untuk memberikan informasi mengenai karakteristik variabel - variabel penelitian yaitu jumlah pengamatan nilai minimum, nilai maksimum, nilai mean, dan standar deviasi (Sugiyono, 2014:207). Hasil dari statistik deskriptif penelitian dapat dilihat pada Tabel 1 berikut:

Tabel 1.

Hasil Statistik Deskriptif Variabel Penelitian

\begin{tabular}{llrrrr}
\hline & N & Minimum & Maximum & Mean & Std. Deviation \\
\hline Kemampuan Pengguna & 165 & 2.00 & 4.00 & 3.0657 & .40101 \\
Keterlibatan Pengguna & 165 & 2.00 & 4.00 & 2.9744 & .45757 \\
Budaya Oganisasi & 165 & 2.00 & 3.84 & 2.9892 & .37705 \\
Keefektifan Penggunaan SIA & 165 & 2.00 & 3.79 & 3.0351 & .36058 \\
Valid N (listwise) & 165 & & & & \\
Sumber : Data diolah, 2018 & & & & &
\end{tabular}

Berdasarkan hasil uji statistik deskriptif pada Tabel 1 dapat diketahui bahwa total sampel yang digunakan adalah 165 orang responden. Hasil statistik deskriptif dalam penelitian ini dapat dijelaskan sebagai berikut:

Variabel kemampuan pengguna memiliki nilai minimum sebesar 2,00 dan nilai maksimum sebesar 4,00. Variabel kemampuan pengguna yang diukur dengan 6 item pernyataan dengan bantuan skala likert 4 poin memiliki nilai rata-rata sebesar 3,06. Rentang kriteria untuk variabel kemampuan pengguna adalah sebagai berikut :

$$
\begin{aligned}
& \text { Nilai Interval : Skor maksimum }- \text { Skor minimun }=4-1=3 \\
& \text { Range : } \frac{\text { Nilai Interval }}{\text { Jumlah Kelas }}=\frac{3}{4}=0,75
\end{aligned}
$$


ISSN: 2302-8556

E-Jurnal Akuntansi Universitas Udayana

Vol.26.1.Januari (2019): 281-309

Skor pada penelitian ini memiliki nilai tertinggi maksimal 4 dan terendah minimal 1, sehingga dapat disusun kriteria pengukuran sebagai berikut :

\section{Tabel 2.}

\section{Kriteria Pengukuran}

\begin{tabular}{cc}
\hline Nilai Skor & Kriteria Variabel Kemampuan pengguna \\
\hline $1,00-1,75$ & Sangat Tidak Baik \\
$1,76-2,50$ & Tidak Baik \\
$2,51-3,25$ & Baik \\
$3,26-4,00$ & Sangat Baik \\
\hline
\end{tabular}

Sumber: Data diolah, 2018.

Kriteria pengukuran tersebut menunjukkan bahwa semakin tinggi nilai rata-rata yang diperoleh menunjukkan semakin baik tanggapan responden terhadap item maupun variabel tersebut. Nilai rata-rata variabel kemampuan pengguna sebesar 3,06 berada pada kriteria baik yaitu pada rentang nilai 2,513,25, maka dapat dikatakan bahwa kemampuan pengguna pada SPPBE di Provinsi Balisudah baik. Nilai standar deviasi variabel kemampuan penggunasebesar 0,401 . Hal ini berarti nilai ini lebih rendah dibandingkan dengan nilai rata-rata, yang artinya sebaran data terkait dengan kemampuan pengguna sudah merata.

Variabel keterlibatan pengguna memiliki nilai minimum sebesar 2,00 dan nilai maksimum sebesar 4,00. Variabel keterlibatan pengguna yang diukur dengan 9 item pernyataan dengan bantuan skala likert 4 memiliki nilai ratarata sebesar 2,97. Nilai rata-rata variabel keterlibatan pengguna sebesar 2,97 berada pada kriteria tinggi yaitu pada rentang nilai 2,51-3,25 yang dapat 
Putu Pande Ryan Ananta Astika Putra dan I G.A.M. Asri Dwija Putri. Pengaruh...

dilihat pada Tabel 2, maka dapat dikatakan bahwa pengguna sistem informasi pada SPPBE di Provinsi Balisudah memiliki keterlibatan yang tinggi. Nilai standar deviasi variabel keterlibatan pengguna sebesar 0,45. Hal ini berarti nilai ini lebih rendah dibandingkan dengan nilai rata-rata, yang artinya sebaran data terkait keterlibatan pengguna sudah merata.

Variabel budaya organisasi memiliki nilai minimum sebesar 2,00 dan nilai maksimum sebesar 3,84. Variabel budaya organisasi yang diukur dengan 32 item pernyataan dengan bantuan skala likert 4 memiliki nilai rata-rata sebesar 2,98. Nilai rata-rata variabel budaya organisasi sebesar 2,98 berada pada kriteria baik yaitu pada rentang nilai 2,51-3,25 dapat dilihat pada Tabel 2, maka dapat dikatakan bahwa budaya organisasi pada SPPBE di Provinsi Balisudah baik. Nilai standar deviasi variabel budaya organisasi sebesar 0,37. Hal ini berarti nilai ini lebih rendah dibandingkan dengan nilai rata-rata, yang artinya sebaran data terkait sudah merata.

Variabel keefektifan penggunaan Sistem Informasi Akuntansi memiliki nilai minimum sebesar 2,00 dan nilai maksimum sebesar 3,79. Variabel keefektifan penggunaan Sistem Informasi Akuntansi yang diukur dengan 14 item pernyataan dengan bantuan skala likert 4 memiliki nilai ratarata sebesar 3,03. Nilai rata-rata variabel keefektifan penggunaan Sistem Informasi Akuntansi sebesar 3,03 berada pada kriteria baik yaitu pada rentang nilai 2,51-3,25 yang dapat dilihat pada Tabel 2, maka dapat dikatakan bahwa penggunaan Sistem Informasi Akuntansi pada SPPBE di Provinsi Balisudah 
ISSN: 2302-8556

E-Jurnal Akuntansi Universitas Udayana

Vol.26.1.Januari (2019): 281-309

efektif. Nilai standar deviasi variabel keefektifan penggunaan Sistem Informasi Akuntansi sebesar 0,36. Hal ini berarti nilai ini lebih rendah dibandingkan dengan nilai rata-rata, yang artinya sebaran data terkait sudah merata.

Tujuan dilakukan nyauji normalitas yaitu untuk menguji apakah dalam residual dari model regresi yang dibuat telah berdistribusi normal. Uji Komogorov-Sminarnov dilakukan untuk menguji uji normalitas. Nilai Asymp. Sig. (2-tailed) yang disajikan pada Tabel 3 yaitu sebesar 0,683, yang dimana lebih besar dari 0,05 maka dapat disimpulkan bahwa seluruh data berdistribusi normal.

Tabel 3.

\section{Hasil Uji Normalitas}

\begin{tabular}{llr}
\hline & & $\begin{array}{c}\text { Unstandardized } \\
\text { Residual }\end{array}$ \\
\hline $\mathrm{N}$ & & 35 \\
Normal Parameters & Mean & .0000000 \\
& Std. Deviation & .76012548 \\
Most Extreme Differences & Absolute & .121 \\
& Positive & .121 \\
& Negative & -.058 \\
Kolmogorov-Smirnov Z & & .717 \\
Asymp. Sig. (2-tailed) & & .683 \\
\hline umber: Data diolah,2018 & &
\end{tabular}

Tujuan dilakukannya uji heteroskedatisitas yaitu untuk menguji apakah dalam model regresi terjadi ketidaksamaan variance dari residual untuk semua pengamatan. Uji Glejser digunakan untuk menguji uji heterokedastisitas di dalam penelitian ini. Apabila tingkat signifikansi lebih besar dari $\alpha=0,05$ maka model regresi yang 
dianalisis tidak adanya gejala heteroskedastisitas. Pada Tabel 4 disajikan hasil uji heteroskedastisitas berikut ini.

\section{Tabel 4.}

Hasil Uji Heteroskedastisitas

\begin{tabular}{cccc}
\hline Persamaan & Variabel & T & Sig \\
\hline & Kualitas SIA $\left(\mathrm{X}_{1}\right)$ & 1,718 & 0,096 \\
$\mathrm{Y}=\mathrm{a}+\beta_{1} \mathrm{X}_{1}+\beta_{2} \mathrm{X}_{2}+\beta_{3} \mathrm{X}_{1} \mathrm{X}_{2}+\mathrm{e}$ & Ketidakpastian tugas $\left(\mathrm{X}_{2}\right)$ & $-1,063$ & 0,296 \\
& $\begin{array}{c}\text { Interaksi antara kualitas SIA } \\
\text { dengan ketidakpastian tugas } \\
\left(\mathrm{X}_{1} * \mathrm{X}_{2}\right)\end{array}$ & 0,080 & 0,937 \\
\hline
\end{tabular}

Sumber : Data diolah, 2018

Dari hasil pengujian pada Tabel 4, tingkat signifikansi seluruh variabel berada diatas 0,05 hal ini menunjukkan model regresi moderasi dalam penelitian ini bebas dari heteroskedastisitas.

Tujuan dilakukannya uji multikolinieritas yaitu untuk menguji apakah dalam model regresi ditemukan adanya korelasi antara variabel independen. Nilai cut off yang dipakai untuk menunjukkan adanya multikolinearitas adalah nilai VIF $\geq 10$ atau nilai tolerance $\leq 0,10$. Pada Tabel 5disajikan Hasil uji multikolinieritas sebagai berikut.

\section{Tabel 5.}

Hasil Uji Multikolinieritas

\begin{tabular}{llccc}
\hline \multicolumn{1}{c}{ Variabel } & & Tolerance & VIF & Keterangan \\
\hline Kualitas Pelayanan & $\left(\mathrm{X}_{1}\right)$ & 0,503 & 1,989 & Bebas Multikolinieritas \\
Sanksi Pajak & $\left(\mathrm{X}_{2}\right)$ & 0,523 & 1,913 & Bebas Multikolinieritas \\
Biaya KepatuhanPajak & $\left(\mathrm{X}_{3}\right)$ & 0,475 & 2,107 & Bebas Multikolinieritas \\
Penerapan e-Filling & $\left(\mathrm{X}_{4}\right)$ & 0,384 & 2,607 & Bebas Multikolinieritas \\
\hline
\end{tabular}
Sumber : Data diolah, 2018

Berdasarkan hasil perhitungan tabel diatas, nilai nilai tolerance lebih besar dari 0,1dan nilai VIF lebih kecil dari 10, Sehingga disimpulkan bahwa antar variabel independen tidak terjadi atau bebas multikolinearitas. 
ISSN: 2302-8556

E-Jurnal Akuntansi Universitas Udayana Vol.26.1.Januari (2019): 281-309

Pengujian data dalam penelitian ini menggunakan teknik analisis regresi moderasi.Uji regresi moderasi/MRA bertujuan untuk mengetahui apakah variabel moderasi yaitu budaya organisasi mampu mempengaruhi hubungan antara variabel bebas dan variabel terikat, dimana dalam persamaan regresinya mengandung unsur interaksi.Perhitungan koefisien regresi moderasi dilakukan dengan analisis regresi melalui software SPSS for Windows, diperoleh hasil yang ditunjukan pada Tabel 6 sebagai berikut.

Tabel 6.

Hasil Analisis Regresi Moderasi

\begin{tabular}{|c|c|c|c|c|c|}
\hline \multirow[t]{2}{*}{ Model } & \multicolumn{2}{|c|}{$\begin{array}{c}\text { Unstandardized } \\
\text { Coefficients }\end{array}$} & \multirow{2}{*}{$\begin{array}{c}\text { Standardized } \\
\text { Coefficients } \\
\text { Beta }\end{array}$} & \multirow[b]{2}{*}{$\mathrm{t}$} & \multirow[b]{2}{*}{ Sig. } \\
\hline & $\mathrm{B}$ & Std. Error & & & \\
\hline 1 (Constant) & -.014 & .035 & & -.396 & .693 \\
\hline Kemampuan Pengguna & .400 & .052 & .363 & 7.663 & .000 \\
\hline Keterlibatan Pengguna & .193 & .090 & .188 & 2.130 & .035 \\
\hline Budaya Oganisasi & -.003 & .092 & -.003 & -.032 & .974 \\
\hline $\mathrm{X} 1 . \mathrm{X} 3$ & .420 & .056 & .405 & 7.547 & .000 \\
\hline $\mathrm{X} 2 . \mathrm{X} 3$ & .126 & .047 & .126 & 2.693 & .008 \\
\hline R Square & & & & & 0,806 \\
\hline Adjusted R Square & & & & & 0,800 \\
\hline F Statistik & & & & & 131,856 \\
\hline Signifikansi & & & & & 0,000 \\
\hline
\end{tabular}

Sumber :Data diolah, 2018.

Berdasarkan tabel diatas dapat disusun persamaan regresi adalah sebagai berikut.

$$
Y=0,400 X_{1}+0,193 X_{2}-0,003 X_{3}+0,420 X_{1} \cdot X_{3}+0,126 X_{2} \cdot X_{3}+e
$$

Nilai koefisien regresi variabel kemampuan pengguna bernilai positif dengan nilai signifikansi uji t kurang dari 0,05. Hal ini menunjukkan bahwa variabel kemampuan pengguna memiliki pengaruh positif yang signifikan terhadap variabel terikat. Nilai koefisien regresi variabel keterlibatan pengguna bernilai positif dengan nilai signifikansi uji $\mathrm{t}$ lebih dari 0,05. Hal ini menunjukkan bahwa variabel 
Putu Pande Ryan Ananta Astika Putra dan I G.A.M. Asri Dwija Putri. Pengaruh...

keterlibatan pengguna berpengaruh secara signifikan terhadap variabel terikat. Sedangkan nilai koefisien regresi variabel Interaksi (budaya organisasi) Antara kemampuan pengguna dan keterlibatan pengguna terhadap budaya organisasibernilai positif dengan nilai signifikansi uji t lebih dari 0,05 . Hal ini menunjukkan bahwa variabel Interaksi Antara kemampuan pengguna dan keterlibatan pengguna denganbudaya organisasi berpengaruh secara positif signifikan terhadap variabel terikat.

Nilai Adjusted R Square model (Uji koefisien determinasi) pada tabel 6 uji analisis regresi moderasi sebesar 0,800 artinya 80 persen efektifitas SIA dipengaruhi oleh kemampuan pengguna, keterlibatan pengguna dan budaya organisasi, sedangkan 20 persen dijelaskan oleh variabel lain diluar model.

Hasil uji F (Ftest) pada tabel 6menunjukkan bahwa nilai signifikansi Fvalue 0,000 yang lebih kecil dari $\alpha=0,05$, ini berarti model yang digunakan pada penelitian ini adalah layak. Hasil ini memberikan makna bahwa seluruh variabel independen yaitu kemampuan pengguna, keterlibatan pengguna dan variabel interaksi antara kemampuan dan keterlibatan pengguna pada budaya organisasi mampu memprediksi atau menjelaskan fenomena Efektifitas SIA.

Berdasarkan hasil uji analisis regresi moderasi, menunjukkan pengaruh kemampuan pengguna diperoleh nilai signifikansi sebesar $0,000<0.05$ (significant) dengan nilai koefisien regresi sebesar 0,400, yang berarti bahwa kemampuan pengguna berpengaruh positif dan signifikan pada keefektifitas SIA. Hal tersebut menunjukkan bahwa semakin baik kemampuan penggunaan SIA yang dimiliki oleh 
ISSN: 2302-8556

karyawan, maka akan mempengaruhi peningkatan keefektifan penggunaan sistem informasi akuntansi di perusahaan SPPBE di Bali.Begitu juga sebaliknya semakin buruk kemampuan karyawan dalam menggunakan sistem informasi akuntansi, maka akan semakin mengurangi keefektifan penggunaan sistem informasi akuntansi di perusahaan SPPBE di Bali

Pengguna sistem informasi merupakan fokus yang penting berkaitan dengan efektifitas sistem informasi, karena pengguna sistem informasi lebih banyak mengetahui permasalahan yang terjadi dilapangan.Hasil penelitian ini mengacu pada teori Technology Acceptance Model. Berdasarkan teori ini menggambarkan bahwa kemampuan perlu untuk dimiliki oleh pengguna SIA karena semakin baik kemampuan teknik pemakai dapat mendorong pemakai dalam penggunaan SIA sehingga dapat meningkatkan kinerja SIA. Semakin baiknya kemampuan teknik dari pemakai dapat meningkatkan kepuasan pemakai dalam penggunaan SIA sehingga dapat mendorong pemakai untuk terus menggunakannya dalam membantu menyelesaikan pekerjaannya.

Hasil penelitian ini didukung oleh hasil penelitian yang dilakukan oleh Perbani (2014), Daryani (2013) serta Kharisma dan Juliarsa (2017) yang mendapatkan hasil bahwa kemampuan pengguna memiliki pengaruh yang signifikan terhadap kinerja sistem informasi akuntansi perusahaan. Kemampuan dari pengguna sistem informasi menentukan efektif tidaknya sistem informasi akuntansi yang diterapkan oleh perusahaan tersebut, semakin tinggi kemampuan pengguna dalam mengaplikasikan 
Putu Pande Ryan Ananta Astika Putra dan I G.A.M. Asri Dwija Putri. Pengaruh...

sistem informasi akuntansi perusahaan maka akan semakin efektif penggunaan sistem informasi akuntansi di perusahaan tersebut.

Berdasarkan hasil uji analisis regresi moderasi, juga menunjukkan pengaruh keterlibatan pengguna diperoleh nilai signifikansi sebesar $0,035<0.05$ (significant) dengan nilai koefisien regresi sebesar 0,195, yang berarti bahwa keterlibatan pengguna berpengaruh positif dan signifikan pada keefektifitas SIA. Hal ini berarti bahwa semakin baik keterlibatan karyawan dalam menggunakan sistem informasi akuntansi, maka akan semakin meningkatkan keefektifan penggunaan sistem informasi akuntansi di perusahaan SPPBE di Bali. Keterlibatan pengguna merupakan keterlibatan dalam proses pengembangan sistem oleh anggota organisasi atau anggota dari kelompok pengguna target. Hasil penelitian ini mengacu pada teori Technology Acceptance Model. Berdasarkan teori ini menggambarkan bahwa keterlibatan pengguna dalam menggunakan SIA diperusahaan sangat diperlukan karena semakin tinggi tingkat keterlibatan personal pada SPPBE di Bali maka efektivitas pengunaan SIA pada SPPBE di Bali akan semakin meningkat, sebaliknya semakin rendah keterlibatan personal pada pada SPPBE di Bali maka efektivitas penggunaan SIA akan semakin menurun.

Hasil penelitian ini sesuai dengan hasil penelitian yang dilakukan oleh Komara (2005) dan Perbarini (2014) serta Kharisma dan Juliarsa (2017) yang menemukan bahwa keterlibatan pemakai berpengaruh signifikan terhadap keefektifan kinerja sistem informasi akuntansi dalam perusahaan. Penelitian ini juga didukung dengan hasil penelitian dari Surya dan Suardikha (2016) yang mendapatkan hasil bahwa 
ISSN: 2302-8556

E-Jurnal Akuntansi Universitas Udayana

Vol.26.1.Januari (2019): 281-309

keterlibatan pemakai berpengaruh positif dan signifikan terhadap keefektifan kinerja sistem informasi akuntansi perusahaan.

Berdasarkan hasil uji analisis regresi moderasi, variabel kemampuan pengguna dengan budaya organisasi sebagai variabel moderasi menunjukan tingkat signifikansi $0,000<0,05$ dengan nilai koefisien regresi sebesar 0,420 , hal ini berarti bahwa budaya organisasi secara statistik mampu memoderasi pengaruh kemampuan pengguna padakeefektifitas penggunaan SIA. Hal ini menunjukkan bahwa dengan adanya kondisi budaya organisasi yang mendukung, maka pengaruh positif kemampunan pengguna terhadap keefektifan penggunaan SIA akan semakin meningkat.

Komponen budaya yang menjadi fokus kajian adalah kestabilan emosi pengguna setelah melewati fase perubahan akibat implementasi SI (restoring personal emotional stability), perilaku efektif dan efisien dalam bekerja, serta inisiatif untuk ikut serta meminimalkan dampak negatif pasca implementasi sistem informasi.Hasil penelitian ini mengacu pada teori keagenan. Penelitian Nyberg, et al. (2010) juga mengemukakan bahwa dalam teori agensi dapat terjadi konflik bila kepentingan pemilik dan manajer berbeda dan solusi untuk masalah agensi ini adalah keselarasan antara kepentingan pemilik dan manajer. Budaya Organisasi dapat mempengaruhi sifat atau kebiasaan dari karyawan dalam suatu perusahaan, dengan begitu budaya perusahaan akan berpengaruh langsung pada kemampuan dan juga keterlibatan pengguna sistem informasi akuntansi. 
Putu Pande Ryan Ananta Astika Putra dan I G.A.M. Asri Dwija Putri. Pengaruh...

Selain itu hasil analisis regresi moderasi juga menunjukkan bahwa budaya organisasi secara statistik mampu memoderasi pengaruh keterlibatan pengguna terhadap keefektifan penggunaan sistem informasi akuntansi di Perusahaan SPPBE di Bali. Pada penelitian ini, budaya organisasi memperkuat pengaruh keterlibatan pengguna terhadap keefektifan penggunaan SIA. Hal ini menunjukkan bahwa dengan adanya kondisi budaya organisasi yang mendukung, maka keterlibatan pengguna secara langsung akan semakin meningkat, sehingga penggunaan sistem informasi akuntansi di Perusahaan SPPBE di Bali akan semakin ekeftif.

Hasil penelitian ini mengacu pada teori keagenan. Penelitian Nyberg, et al. (2010) juga mengemukakan bahwa dalam teori agensi dapat terjadi konflik bila kepentingan pemilik dan manajer berbeda dan solusi untuk masalah agensi ini adalah keselarasan antara kepentingan pemilik dan manajer. Berkaitan dengan teori tersebut, maka untuk dapat menyelaraskan kepentingan pemilik dan anggotanya maka perusahaan harus memperkuat budaya organisasinya.

Berdasarkan pembahasan yang telah diuraikan terdapat beberapa implikasi penelitian yang dapat dimanfaatkan adalah Penelitian ini menghasilkan bukti empiris bahwa dapat memberikan kontribusi mengenai pengaruh kemampuan pengguna dan keterlibatan pengguna pada keefektifan sistem informasi akuntansi dengan budaya organisasi sebagai variabel moderasi. Hasil uji hipotesis dalam penelitian ini ditemukan bahwa budaya organisasi secara statistik mampu memoderasi pengaruh kemampuan pengguna dan keterlibatan pengguna pada keefektifan sistem informasi 
ISSN: 2302-8556

akuntansi di Perusahaan SPPBE di Bali, sehingga variabel tersebut dapat dipertahankan sebagai variabel pemoderasi.

\section{SIMPULAN}

Berdasarkan hasil penelitian yangtelah dijelaskan sebelumnya, simpulan yang diperoleh adalah penelitian inikemampuan pengguna dan keterlibatan pengguna berpengaruh positif dan signifikan pada keefektifitas penggunaan SIA serta budaya organisasi mampumemoderasi pengaruh kemampuan penggunan dan keterlibatan pengguna pada keefektifan penggunaan SIA, Hal ini menunjukkan bahwa terdapat interaksi budaya organisasi pada kemampuan pengguna dan keterlibatan pengguna dalam mempengaruhi keefektifan penggunaan SIA. Budaya organisasi akan membuat karyawan semakin terdorong dalam berprestasi maka, dengan kuatnya budaya organisasi perusahaan akan memperkuat dan semakin membuat karyawan terlibat dalam penggunaan sistem informasi akuntansi yang akan membuat pengaplikasian sistem informasi akuntansi yang dimiliki oleh perusahaan tersebut semakin efektif.

Saran yang dapat peneliti usulkan berdasarkan hasil penelitian dan simpulan yang telah diuraikan di atas adalahuntuk meningkatkan keefektifan penggunaan sistem informasi akuntansi, sebaiknya perusahaan SPPBE di Bali diharapkan dapat memberikan pendidikan dan pelatihan secara berkala kepada karyawan SPPBE agar karyawan memiliki kemampuan yang baik dalam menggunakan sistem informasi akuntansi perusahaan sehingga dapat menghemat waktu serta mengefektifkan pekerjaan yang dilakukan dengan menggunakan SIA. Selain itu, Perusahaan 
Putu Pande Ryan Ananta Astika Putra dan I G.A.M. Asri Dwija Putri. Pengaruh...

sebaiknya tetap memperhatikan budaya organisasi yang diterapkan oleh SPPBE yang nantinya dapat menjadi dasar dalam melaksanakan pendidikan dan pelatihan unit kerja guna meningkatkan kemampuan dan keterlibatan karyawan dalam menggunakan sistem informasi akuntansi. Untuk peneliti selanjutnya diharapkan dapat memperluas ruang lingkup wilayah penelitian tidak hanya pada lingkup daerah tertentu saja, melainkan mencakup lingkup daerah yang lebih luas serta pada instansi yang berbeda, sehingga dapat mewakili populasi dengan jumlah yang lebih besar. Penelitian selajutnya disarankan untuk menambahkan variabel bebas ataupun variabel moderasi lainnya untuk menunjang kompleksitisitas penelitian, misalnya menambahkan variabel dukungan manajemen atau variabel kepercayaan pengguna.

\section{REFERENSI}

Aberg MA, Waem m, Nyberg J et al. Cardiovascular Fitness in Males at age 18 and Risk of Serious Depression in Adulthood: Swedish Prospective Population based Study.2012;201:352-59

Ahmad Al-Hiyari, Mohammed Hamood Hamood AL-Mashre, Nik Kamariah Nik Mat , Jamal Mohammedesmail alekam., 2013, "Factors that Affect Accounting Information System Implementation and Accounting Information Quality: A Survey in University Utara Malaysia”, American Journal of Economics 2013, 3(1): 27-31

Aikins, JR. 2012. Predictor of Positive Adjusment in Children Exposed to the Deepwater Horizon Oil Spill and Hurricane Katrina. Thesis. Texas: The Departement of Psychology

Ali, Irfan (2002). Pelaporan Keuangan dan Asimetri Informasi dalam Hubungan Agensi.Jurnal Lintasan Ekonomi Vol. XIX. No.2. Juli 2002.

Almilia, Luciana Spica dan Irmaya Briliantien. 2007. Faktor-Faktor Yang Mempengaruhi Kinerja Sistem Informasi Akuntansi Pada Bank Umum Pemerintah Di Wilayah Surabaya Dan Sidoarjo. JurnalSTIE Perbanas Surabaya, 14. Hal 57-74. 
ISSN: 2302-8556

E-Jurnal Akuntansi Universitas Udayana

Vol.26.1.Januari (2019): 281-309

Aplonia, Elfreda Lau. 2004. Pengaruh Partisipasi Pemakai terhadap Kepuasan Pemakai dalam Pengembangan Sistem Informasi dengan Lima Variabel Moderating.Jurnal Riset Akuntansi Indonesia, Vol. 7, No. 1, Juli 2004.

Doll, W.J., and G. Torkzadeh. 1989. "The Measurement of End-User Computing Satisfaction". MIS Quarterly. 12 (June). pp. 259-274.

Eisenhardt, Kathleem. (1989). Agency Theory: An Assesment and Review. Journal ofAcademy of Management Review, 14. Hal 57-74.

Galang Rahadian Prabowo, A. M. (2014). Faktor-Faktor yang Mempengaruhi Kinerja Sistem Informasi Akuntansi.Accounting Analysis Journal, 3(1), pp:1-9.

Handayani, Rini. 2007.Analisis Faktor-faktor yang Mempengaruhi Minat Pemanfaatan Sistem Informasi dan Penggunaan Sistem Informasi. Jurnal Akuntansi dan Keuangan, Vol 9(2), h:79-80.

Hendriksen E.S,dan M.F. Van Breda. 2001. Accounting Theory, Edisi 5. Mc GrawHill. New York

Jen Tjhai Fung, 2002, Faktor-Faktor yang Mempengaruhi Kinerja Sistem Informasi Akuntansi. Jurnal Bisnis dan Akuntasi, Vol.4 No 2, h:135-154

Jensen \& Meckling, 1976, The Theory of The Firm: Manajerial Behaviour, Agency Cost, and Ownership Structure, Journal of Financial and Economics, 3:305360 .

Jones, M.G., \& Farquhar, J.D. (1997). User Interfance design for web-based instrunction. Journal Educational Technology Publication, 3, pp:305-360.

Jong Min Choe. 1996. The Relationship Among Performance of Accounting Information Systems, Influence Factors and Evolution Level of Information Systems. Journal of Management Information Systems, 12(4), pp:215-239.

Kusumastuti, M.Cherta dan Irwandi, S.Agus. 2012. Investigasi Empat Faktor Kontigensi Sebagai Variabel Moderating Terhadap Partisipasi Pemakai dan Kepuasan Pemakai Dalam Pengembangan Sistem Informasi. Jurnal Akuntansi Fakultas Ekonomi STIE Parbanas, 2(2) h:139:150.

Kusumawardani, Meilia Resita Puji. 2015. Analisis Ketepatan Model Altman, Springate, Dan ZMijweski Dalam Memprediksi Perusahaan Yang Delisting Di 
Bursa Efek Indonesia Periode 2009-2013. Jurnal Fakultas Ekonomi Universitas Sanata Dharma Yogyakarta,1(2) h:139:150.

Prabowo, Rizky. 2013."Faktor-Faktor Yang Mempengaruhi Kinerja Sistem Informasi Akuntansi Di Bank Umum Kota Surakarta”. JUPE UNS, vol. 2, No.1, Hal 119 s/d 130.

Putri, Yasinta., Putra, I.M.P.Dwiana., 2017, Pengaruh Prinsip-Prinsip Good Corporate Governance, Motivasi, Dan Budaya Organisasi Terhadap Kinerja Karyawan, E-Jurnal Akuntansi Universitas Udayana, Vol.21.2. (2017): 16601688.

Putri, I.G.A.M. Asri Dwija., 2012, Peran Good Corporate Governance dan Budaya terhadap Kinerja Organisasi. Jurnal Akuntansi dan Binsis AUDI, Vol.7, No.2, Juli 2012.

Remeyi, Dan Arthur Money, and Michael Sherwood-Smithwith Zahir Irani. 2002. The Effective Measurement and Management of IT Costs an Benefits, $2^{\text {nd }}$ Edition. Journal Economic of Butterworth-Heineman ,Britain.4, pp:102-360.

Scott, Besley., Eugene F, Bringham, 2000. Essentials of Managerial Finance, Jornal Ekonomic of Orlando:Harcourt Inc. 2(1), pp:50-89.

Soedjono, 2005."Pengaruh Budaya Organisasi Terhadap Kinerja Organisasi dan Kepuasan Kerja Karyawan pada Terminal Penumpang Umum di Surabaya", Jurnal Akuntansi Sekolah Tinggi Ilmu Ekonomi Indonesia (STIESIA) Surabaya, VOL. 7, NO.1, MARET 2005: 22- 47.

Soegiharto. 2001. "Influence Factors Affecting The Performance Of Accounting Information System”. Gajah Mada International Journal of Business Volume III No. 2.[11]

Tjhai, Fung Jen. 2002."Faktor-Faktor Yang Mempengaruhi Kinerja Sistem Informasi Akuntansi ".Jurnal Bisnis dan Akuntansi Vol. IV No. 2.

Wibowo, Agung Nur. Pengaruh Faktor Kesesuaian Tugas-Teknologi dan Pemanfaatan Teknologi Informasi Terhadap Kineija Auditor.Jurnal Universitas Muhammadiyah Surakarta, 2(1), h:60-87.

Wilkinson, Josep W. Et al, 2000. Accounting Information System Essential Concept and Application, Journal of Technology ResearchNew York-USA, Vol. 1, Pp. $1-11$. 
ISSN: 2302-8556

E-Jurnal Akuntansi Universitas Udayana

Vol.26.1.Januari (2019): 281-309

Xu, Hongjiang. April 2009. Data Quality Issues for Accouting Information Sytems Implementation : System, Stakeholders, and Organizational Factors. Journal of Technology Research, Vol. 1, Pp. 1-11. 